Yevhen Sydorenko ${ }^{1}$, Helen Makogon ${ }^{2}$, Mykyta Korda $^{2}$, Oleksandr Isakov², Yuri Babkin ${ }^{2}$, Igor Kalinin ${ }^{2}$

${ }^{1}$ Central Armored Department of the Logistics Forces Armament Command of the AF of Ukraine, Kyiv

${ }^{2}$ Military Institute of Tank Troops of National Technical University "KhPI", Kharkiv, Ukraine

\title{
APPLICATION PROBABILISTIC ECONOMIC MATHEMATICAL MODELS FOR OPTIMIZATION PLANNING OF AN IRREDUCIBLE STOCK AND IMPROVING THE EFFICIENCY OF LOGISTICS SUPPLY MANAGEMENT OF THE STATE DEFENCE FORCES WITHOUT REDUSING THE LEVEL OF RELIABILITY
}

\begin{abstract}
The subject matter of the article is the logistical support of the state defence forces. The goal of the study is the is the development of a probabilistic economic and mathematical model of logistics supply management for planning a nonreducing stock of the state defence forces logistics supply. The tasks to be solved are: to formulate the task of determining the irreducible (reserve) of logistics supply stock size, to provide that the maximum possible value of its probability exhaustion within a certain period will not exceed the limiting value in terms of Wilson economic and mathematical model; by statistical processing of the state defence forces actions observation performing their assigned tasks to present the task of determining the optimal non-reducing stock by type of logistics cost without to reducing the level of reliability as a task to test multi-alternative statistical hypotheses; on the basis of solving the problem of continuous linear programming to determine the optimal nonreducible stock according to the nature of expenditures in order to improve the logistics supply management of the state defence forces. General scientific and special methods of scientific knowledge are used. The following results were obtained: Loses of the logistics supply stocks the defense state forces performing their assigned tasks within a certain period of time as a normally distributed random variable with a mathematical expectation and standard deviation calculated from the results of statistical data processing. The problem of determining the optimal irreducible stock by types of loses of the logistics supply without reducing the level of reliability is formulated as a problem of multi-alternative statistical hypotheses testing and solved as a problem of continuous linear programming. Conclusions. It was determined the size of the non-reducing (reserve) stock of logistics supply of state defense units when performing their assigned tasks, provided that the maximum possible value of the probability of its exhaustion during a certain period does not exceed the limit value should be formulated in terms of Wilson economic-mathematical model. The assumption that the expenditure of the logistics supply stocks means when performing the assigned tasks by the state defense forces is a random variable subject to the normal distribution law make it possible to use the well-known theory of probability apparatus and many-alternative statistical hypotheses testing and make calculations based on the existing statistical sampling data. Statistical processing of data obtained during state defense forces preforming assigned tasks allows you to obtain initial data and calculate the predicted optimal probabilities of the logistics supply loses distribution in accordance with current, average, overhaul and irrecoverable losses.
\end{abstract}

Keywords : logistics support; irreducible stocks; Wilson model; economic and mathematical models; multi-alternative statistical hypotheses; continuous linear programming.

\section{Introduction}

Formulation of the problem and research tasks. The experience of modern armed conflicts encourages the search for new approaches to the formation of prospects for the development of armaments and equipment and areas for improving the equipment of the state defense forces (SDF). The development of new economic and mathematical models will make it possible to provide a comprehensive reflection of the basic parameters and characteristics of the logistics system and improve effective ways to manage the equipment of SDF. At the organization of drugs of divisions of forces of SDF there is a necessity to define a non-reducing stock of logistical support (LS). Usually, the need for LS is probabilistic, and the procedure of their restoration is complicated by the specifics of the SDF tasks on purpose.

In this regard, the authors consider it relevant to study and search for new methods for determining the non-reducing stock of LS in order to improve the stockpile management of SDF equipment.

Analysis of recent research and publications of recent research and publications on the above issues shows that the features of the SDF tasks on purpose outline the main problems and areas of development of the theory of justification of decisions on forecasting the cost of LS. To date, there are quite affordable, economical and quite effective methods for determining the magnitude of the projected losses of weapons based on analytical models of combat use of troops. To one degree or another, they take into account the impact on the magnitude of losses of a number of operationaltactical and physical-geographical factors of important factors, in particular, the degree of cover of troops, the degree of enemy fire, operational damage to weapons and more. However, the connection with the deduction of the non-reducing stock of LS by the authors [1-4] is not fully investigated.

A common understanding of the processes of the logistical approach to the evaluation and adoption of sound and concretely formulated decisions on inventory management has proven its effectiveness in the field of economics and business [5,6]. Nevertheless, the application can provide tools to optimize the planning of the minimum stock and increase the efficiency of the state defense forces logistics.

The goal of the study is the is the development of a probabilistic economic and mathematical model of logistics supply management for planning a nonreducing stock of the state defence forces logistics supply. This goal defined the following research tasks: 
- to formulate the task of determining the irreducible (reserve) stock of logistics supply size, to provide that the maximum possible value of its probability exhaustion within a certain period will not exceed the limiting value in terms of Wilson economic and mathematical model;

- by statistical processing of the state defence forces actions observation performing their assigned tasks to present the task of determining the optimal nonreducing stock by type of logistics cost without to reducing the level of reliability as a task to test multialternative statistical hypotheses; on the basis of solving the problem of continuous linear programming to determine the optimal non-reducible stock according to the nature of loses in order to improve the logistics supply management of the state defence forces.

General scientific and special methods of scientific knowledge are used.

\section{Main material}

1. Using Wilson economic-mathematical model to determine the non-reducing stock of LS. Let's assume the daily requirement $x$ of some LS resources (fuel, units of equipment, etc.) by the SDF unit performs the assigned tasks for a certain period of time, is a normally distributed random variable with mathematical expectation $\mathrm{m}$ and standard deviation $\sigma$, i.e. random variable has a distribution $N(m, \sigma)$.

The values of $m$ and $\sigma$ can be calculated by statistical data processing. Note that the values $m$ of $\sigma$ can vary from minimum to maximum depending on the nature of the SDF actions.

It is natural to assume that to replenish LS stocks it takes some time $L$, not more than the time to perform the assigned tasks.

The magnitude of demand during the lead-up period is usually described by a probability density per unit of time (for example, a day or a week) from which the distribution of demand over a period can be determined.

In particular, if the demand per unit of time is a normally distributed quantity with an average value $\mathrm{m}$ and a standard deviation, then the total demand for the period of order execution $L$, will have a distribution $N\left(m_{L}, \sigma_{L}\right)$ such that the average demand value during the period $L$ with the mathematical expectation $m_{L}$ calculated by the expression

$$
m_{L}=D \cdot L \text {, }
$$

where $m-$ is the mathematical expectation of the random value of the daily requirement of LS stocks.

Similarly,

$$
\sigma_{L}=\sqrt{L} \sigma
$$

$\sigma$ - standard deviation of the random value of daily requirement of LS stocks.

That is, the needs $x_{L}$ of some LS resources of the $\mathrm{SDF}$ unit is a random variable subject to the normal distribution law $N\left(m_{L}, \sigma_{L}\right)$.

The task is to determine the size of the irreducible (reserve) stock $B$, provided that the maximum possible value of the probability of its exhaustion during the period $L$ does not exceed the value of $\alpha_{\text {set }}$.

In terms of an economic and mathematical model, the problem is formulated as follows [7]:

to determine the size of the safety stock that satisfies the probabilistic condition

$$
P\left\{x_{L}-m_{L} \geq B\right\} \leq \alpha_{\text {set }},
$$

although the random variable $x_{L}$ is distributed according to the normal law $N\left(m_{L}, \sigma_{L}\right)$.

Dividing the inequality by the value, we obtain

$$
\frac{x_{L}-m_{L}}{\sigma_{L}} \geq \frac{B}{\sigma_{L}} .
$$

Let's introduce a random variable

$$
Z=\frac{x_{L}-m_{L}}{\sigma_{L}} .
$$

Obviously, this value will have a normal distribution law. Let's determine its mathematical expectation and standard deviation:

$$
\begin{gathered}
M(Z)=M ; \\
\left(\frac{x_{L}-m_{L}}{\sigma_{L}}\right)=\frac{1}{\sigma_{L}} M\left(x_{L}-m_{L}\right)= \\
=\frac{1}{\sigma_{L}}\left(M\left(x_{L}\right)-M\left(m_{L}\right)\right)=\frac{1}{\sigma_{L}}\left(m_{L}-m_{L}\right)=0 ; \\
\left(\frac{x_{L}-m_{L}}{\sigma_{L}}\right)=\frac{1}{\sigma_{L}^{2}} D\left(x_{L}-m_{L}\right)=D ; \\
\frac{1}{\sigma_{L}^{2}}\left(D\left(x_{L}\right)-D\left(m_{L}\right)\right)=\frac{1}{\sigma_{L}^{2}} D\left(x_{L}\right)=1 ; \\
\sigma(Z)=\sigma\left(\frac{x_{L}-m_{L}}{\sigma_{L}}\right)=\sqrt{D\left(\frac{x_{L}-m_{L}}{\sigma_{L}}\right)}=1 .
\end{gathered}
$$

Thus, from expressions (6) - (11) it follows that the random variable $Z$ is normalized value with the law of distribution $N(0,1)$.

From the properties of the normal distribution law one can obtain the value of the probability that equality takes place $P\left\{Z \geq B / \sigma_{L}\right\}=\alpha_{\text {set }}$ :

$$
\begin{gathered}
P\left\{Z \geq \frac{B}{\sigma_{L}}\right\}=P\left\{\frac{B}{\sigma_{L}} \leq Z \leq \infty\right\}= \\
=\frac{1}{2}(1-\Phi(t))=\alpha_{\text {set }},
\end{gathered}
$$

where $\mathrm{F}(\mathrm{t})$ - is the Laplace distribution [10].

Expression (11) allows to find $t_{\alpha}$.

Insofar as

$$
t_{\alpha}=B / \sigma_{L},
$$

then 


$$
B=t_{\alpha} \cdot \sigma_{L}
$$

Therefore, the size of the reserve stock must satisfy the inequalities

$$
B \geq t_{\alpha} \cdot \sigma_{L} .
$$

2. Improving the efficiency of logistics supply of the state defense forces based on the use of mathematical apparatus for testing multi-alternative statistical hypotheses. By the nature of their activities, SDF can perform tasks in which the costs of LS loses (e.g., equipment) can be restored by current (CR), average repairs (AR) with their own funds, by overhaul (O) at a state enterprise (SE), or be irreversible (I). The probabilistic nature of LS losses complicates the process of managing the FDF LS to determine the optimal nonreducing stock by type of LS loses without reducing the level of reliability.

The assumption that the LS loses performing SDF assigned tasks is a random variable subject to the normal distribution law will allow us to use the known apparatus of probability theory and test many alternative statistical hypotheses and make calculations based on existing statistical sampling.

According to the classical theory of testing statistical hypotheses, we accept:

$\mathrm{H}_{0}$ - hypothesis, which is that the daily requirement $\mathrm{LS}$ stocks can be restored by $\mathrm{CR}$;

$\mathrm{H}_{1}$ - hypothesis, which is that the daily requirement of LS stocks can be restored by AR;

$\mathrm{H}_{2}$ - hypothesis, which is that the daily requirement of LS stocks can be restored by SE;
$\mathrm{H}_{3}$ - hypothesis, which is that the SDF unit irreversible LS losses

It should be mentioned that the choice of the main hypothesis was made for reasons of the inevitability of the implementation of PR in the operation of LS during the SDF assigned tasks.

Then, the daily LS expenditure $x \in \Omega$ is a random variable with a distribution density $f\left(x / H_{0}\right)$ if hypothesis $\mathrm{H}_{0}$ is correct, and $f\left(x / H_{1}\right), f\left(x / H_{2}\right)$, $f\left(x / H_{3}\right)$ when alternative hypotheses $H_{1}, H_{2}$ or $H_{3}$ are correct, respectively. A priori probabilities of realization of the corresponding hypotheses $P\left(H_{i}\right), i=0,1,2,3$ are considered known. The task is to find a rule according to which according to the results of the analysis of the statistics of LS loses to accept this or that hypothesis and on its basis to determine the required LS stock.

The decision is made using a critical function

$$
0 \leq A(x) \leq 1,
$$

which has sense of the probability of accepting a particular hypothesis.

Acceptance or rejection of hypotheses is accompanied by the possibility of errors. According to the classical theory of statistical hypothesis testing [8,9], the probability of rejecting hypothesis $\mathrm{H}_{0}$, when it is true, is called the level of significance or error of the first kind $\alpha_{0}$. On the other hand, if the hypothesis $\mathrm{H}_{0}$ is accepted in a situation when the hypothesis No is true, and $i=0,1,2,3$, then this is the $i$-th error of the second kind $\beta_{i}$ (Fig. 1).

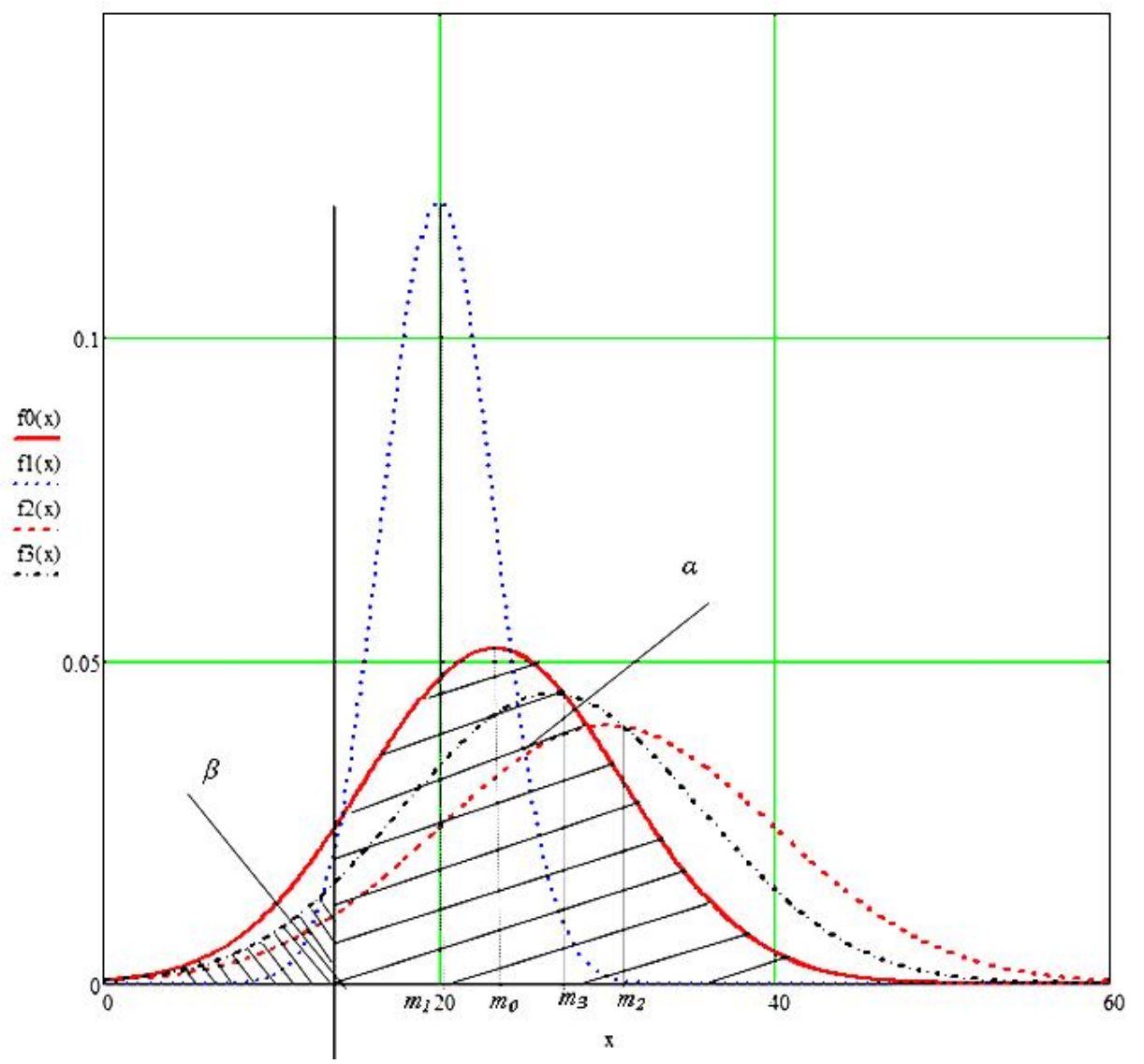

Fig. 1. Testing of multi-alternative statistical hypotheses to increase the efficiency of SDL LS management 
To ensure the required level of combat capability of equipment, it is advisable to accept the condition $\alpha_{0}=\alpha_{\text {set }}$, and the search for a critical function to carry out the criterion of minimum errors of the second kind $\beta_{i}$.

$$
\begin{gathered}
\beta_{i}=\int_{\Omega} f\left(x / H_{i}\right)(1-A(x)) d x= \\
=1-\int_{\Omega} f\left(x / H_{i}\right) A(x) d x, \quad i=\overline{0,3} \\
\beta=\int_{\Omega} \sum_{i=1}^{3} P\left(H_{i}\right) f\left(x / H_{i}\right)(1-A(x)) d x= \\
=1-P\left(H_{0}\right)-\int_{\Omega} \sum_{i=1}^{3} P\left(H_{i}\right) f\left(x / H_{i}\right) A(x) d x \Rightarrow \min ; \\
P\left(H_{0}\right) \int_{\Omega} f\left(x / H_{0}\right) A(x) d x=\alpha_{s e t} \\
0 \leq A(x) \leq 1, x \in \Omega .
\end{gathered}
$$

From expression (18) we determine the power of the criterion, which is subject to maximization:

$$
\int_{\Omega} \sum_{i=1}^{3} P\left(H_{i}\right) f\left(x / H_{i}\right) A(x) d x \Rightarrow \max
$$

Thus, the task of testing hypotheses will be formulated as follows:

To find a function $A^{*}(x)$ that maximizes the functional (20) and satisfies conditions (17) - (19).

By sampling in $n$ steps $(j=\overline{1, n})$ this problem can be reduced to the problem of linear programming:

To find a set

$$
A^{*}=\left\{a_{0}^{*}, a_{1}^{*}, a_{2}^{*}, a_{3}^{*}\right\}
$$

such that maximizes functionality

$$
\sum_{i=0}^{3} \sum_{j=1}^{n} P\left(H_{i}\right) f\left(x_{j} / H_{i}\right) a_{i}(x) d x \Rightarrow \max
$$

and satisfies the constraints

$$
\begin{gathered}
\sum_{i=0}^{3} a_{i}=1, i=\overline{0,3} \\
a_{i} \geq 0, i=\overline{0,3}
\end{gathered}
$$

$$
P\left(H_{0}\right) \sum_{j=1}^{n} f\left(x_{j} / H_{0}\right) a_{0}=\alpha_{\text {set }}
$$

Problem (21) - (25) is a classical problem of linear programming and can be solved by known methods using a computer algebra environment [10-12].

3. Interpretation of the results of calculations to improve the LS management of SDF. Improving the efficiency of SDF LS management is possible under the condition of determining the optimal non-reducing stock according to the nature of loses.

Statistical processing of data obtained during the performance of SDF assigned tasks allows to obtain the initial data and calculate the predicted optimal probabilities (19) of the distribution of LS loses in accordance with $\mathrm{CR}, \mathrm{AR}, \mathrm{O}$ and I losses.

Since the value of the optimal set has the meaning of the conditional probability, i.e. the mass fraction in the total amount, in the final form, condition (14) will be defined as

$$
B_{i}^{*} \geq t_{\alpha i} \cdot \sigma_{\alpha i} a_{i}^{*}, i=\overline{0,3},
$$

where $B_{i}^{*} i=\overline{0,3}$ - is the optimal non-reducing LS stock at the costs that are restored at CR, AR, O and I loses, respectively.

\section{Conclusions}

It was determined the size of the non-reducing (reserve) stock of logistics supply of state defense units when performing their assigned tasks, provided that the maximum possible value of the probability of its exhaustion during a certain period does not exceed the limit value should be formulated in terms of Wilson economic-mathematical model.

The assumption that the expenditure of the logistics supply stocks means when performing the assigned tasks by the state defense forces is a random variable subject to the normal distribution law make it possible to use the well-known theory of probability apparatus and many-alternative statistical hypotheses testing and make calculations based on the existing statistical sampling data.

Statistical processing of data obtained during state defense forces preforming assigned tasks allows you to obtain initial data and calculate the predicted optimal probabilities of the logistics supply loses distribution in accordance with current, average, overhaul and irrecoverable losses.

\section{REFERENCES}

1. Pavlovsky, O.V. (2015), "Forecasting the amount of losses of weapons and military equipment during operations (combat operations)", Systemy ozbroyennya i viys'kova tekhnika, no. 4(44), pp. 116-118.

2. Moskovchenko, V.M. (2001), Ekonomicheskoye obosnovaniye sozdaniya yedinoy sistemy material'nogo obespecheniya silovykh struktur gosudarstva na osnove logisticheskogo podkhoda: monografiya [Economic substantiation of the creation of a unified system of material support for the power structures of the state on the basis of a logistic approach: monograph], Publishing house of St. Petersburg State University of Economics, St. Petersburg, RU.

3. Biletov, V.I. (2010), "The problem of building a unified system of logistical support of military formations of Ukraine", Trudy Nat. University of Defense of Ukraine, vol. 4(91), pp. 81-89.

4. Sysoev, V.V (2015), "The concept of modeling the logistics management of the supply of forces of the security and defense sector of the state", Problems of the economy, vol. 3, pp. 342-251, available at: http://nbuv.gov.ua/UJRN/Pekon_2015_3_47. 
5. Pastukhova, V.V. (2008), Stratehichne upravlinnya pidpryyemstvom: filosofiya, polityka, efektyvnist' [Strategic management of the enterprise: philosophy, policy, efficiency], KNEU, Kyiv, UA.

6. Bondarenko, O.S. (2009), "Modern models of inventory management", Economy and state, no 3, pp. 16-22.

7. Sterligova, A.N. and Semyonova, I.V. (2005), "Optimal Order Size or Wilson's Mysterious Formula”, Logistic \& system, No. 2, 3, pp. 64-69, 62-71.

8. Venttsel, Ye.S. (1969), Probability Theory, A Textbook, Nauka, Fizmatgiz, Moscow, SU.

9. Venttsel, Ye.S. (1972), Operations Research, Sov. Radio, Moscow, SU.

10. Raskin, L.G. and Kirichenko, I.O. (1987), Mathematical Foundations of Operations Research and Analysis of Complex Air Defense Weapon Systems, VIRTA, Kharkiv, UA.

11. Kirichenko, I. O. and Makogon, Ye.A. (1999), "The problem of testing statistical hypotheses as a linear programming problem", Trudy akademiyi, NAOU, Kyiv, UA.

12. Shvachych, H.H. (2000), Liniyna alhebra v rozrakhunkakh seredovyshcha Mathcad: Pidruchnyk [Linear algebra in Mathcad calculations: Textbook], DAUBP, Dnipropetrovs'k, UA.

Received (надійшла) 25.06.2020

Accepted for publication (прийнята до друку) 23.09.2020

\section{ABOUT THE AUTHORS / ВіДOMOCTI ПРО АВTOPIB}

Сидоренко Свген Анатолійович - Заступник начальника Центрального бронетанкового управління Озброєння Командування Сил логістики Збройних Сил України, Центральне бронетанкове управління Озброєння Командування Сил логістики Збройних Сил України, Київ, Україна;

Yevhen Sydorenko - Deputy Chief of the Central Armored Armament Department of the Logistics Forces Command of the Armed Forces of Ukraine; Central Armored Department of the Logistics Forces Armament Command of the Armed Forces of Ukraine, Kyyiv, Ukraine;

e-mail: sidorenkoe49@gmail.com; ORCID: https://orcid.org/0000-0001-6190-5151

Макогон Олена Анатоліївна - кандидат технічних наук, доцент кафедри бронетанкового озброєння та військової техніки, Військовий інститут танкових військ Національного технічного університету “ХПІ”, Харків, Україна;

Helen Makogon - Candidate of Technical Sciences, Associate Professor of the Armored vehicles and military equipment Department, Military Institute of Tank Troops of National Technical University “KhPI”, Kharkiv, Ukraine; e-mail: helmkg@ukr.net; ORCID: https://orcid.org/0000-0003-1112-8707

Корда Микита Володимирович - курсант за профілем кафедри бронетанкового озброєння та військової техніки, Військовий інститут танкових військ Національного технічного університету “ХПІ”, Харків, Україна;

Mykyta Korda - cadet of the Armored weapons and military equipment Department, Military Institute of Tank Troops of National Technical University “Kharkiv Polytechnic Institute”, Kharkiv, Ukraine; e-mail: kordanikita1@,gmail.com; ORCID: https://orcid.org/0000-0003-0630-4948

Ісаков Олександр Володимирович - старший викладач кафедри бронетанкового озброєння та військової техніки, Військовий інститут танкових військ Національного технічного університету “ХПІ”, Харків, Україна;

Oleksandr Isakov - Senior Lecture of the Armored vehicles and military equipment Department, Military Institute of Tank Troops of National Technical University "Kharkiv Polytechnic Institute", Kharkiv, Ukraine; e-mail: alexalex999@ukr.net; ORCID: https://orcid.org/0000-0003-0801-790X

Бабкін Юрій Валерійович - старший викладач кафедри бронетанкового озброєння та військової техніки, Військовий інститут танкових військ Національного технічного університету “ХПI”, Харків, Україна;

Yuri Babkin - Senior Lecture of the Armored weapons and military equipment Department, Military Institute of Tank Troops of National Technical University "Kharkiv Polytechnic Institute", Kharkiv, Ukraine; e-mail: yribabkn@gmail.com; ORCID: https://orcid.org/0000-0001-9156-9523

Калінін Ігор Вікторович - викладач кафедри бронетанкового озброєння та військової техніки, Військовий інститут танкових військ Національного технічного університету “Харківський політехнічний інститут”, Харків, Україна;

Igor Kalinin - Lecture of the Armored weapons and military equipment Department, Military Institute of Tank Troops of National Technical University "Kharkiv Polytechnic Institute”, Kharkiv, Ukraine;

e-mail: kalina7164@ukr.net; ORCID: https://orcid.org/0000-0002-3912-8285

\section{Застосування імовірнісних економіко-математичних моделей для оптимізації планування незнижувального запасу та підвищення ефективності логістичного забезпечення сил оборони держави без зниження рівня надійності \\ Є. А. Сидоренко, О. А. Макогон, М. В. Корда, Ю. В. Бабкін, О. В. Ісаков, І. В. Калінін}

Анотація. Предметом вивчення в статті $€$ логістичне забезпечення сил оборони держави. Метою дослідження $\epsilon$ розробка ймовірнісної економіко-математичної моделі управління запасами для планування незнижувального запасу засобів матеріально-технічного забезпечення сил оборони держави. Завдання дослідження: сформулювати задачу визначення розміру незнижувального (резервного) запасу матеріально-технічних засобів за умови, що максимально можливе значення ймовірності його вичерпання протягом визначеного періоду не перевищить граничного значення у термінах економіко-математичної моделі Уілсона; шляхом статистичної обробки даних спостережень дій сил оборони держави при виконанні ними завдань за призначенням представити задачу визначення оптимального незнижувального запасу за видами витрат засобів матеріально-технічного забезпечення без 
зниження рівня надійності як задачу перевірки багатоальтернативних статистичних гіпотез; на підставі розв'язання задачі континуального лінійного програмування визначити оптимальний незнижувального запасу відповідно характеру витрат з метою підвищення ефективності управління логістичним забезпеченням сил оборони держави засобами матеріально-технічного забезпечення. Методологічною основою дослідження стали загальнонаукові та спеціальні методи наукового пізнання. Отримані такі результати. Витрати запасів матеріально-технічних засобів при виконанні силами оборони держави завдань за призначенням протягом певного періоду часу $є$ нормально розподіленою випадковою величиною 3 математичним очікуванням та середнєквадратичним відхиленням, обрахованими за результатами статистичної обробки даних. Задача визначення оптимального незнижувального запасу за видами витрат матеріально-технічних засобів без зниження рівня надійності сформульована як задача перевірки багатоальтернативних статистичних гіпотез та розв'язана як задача континуального лінійного програмування. Висновки. Визначення розміру незнижувального (резервного) запасу матеріально-технічних засобів підрозділів сил оборони держави при виконанні ними завдань за призначенням за умови, що максимально можливе значення ймовірності його вичерпання протягом визначеного періоду не перевищить граничного значення доцільно сформулювати у термінах економіко-математичної моделі Уілсона. Припущення про те, що витрати запасів матеріально-технічних засобів при виконанні силами оборони держави при виконанні завдань за призначенням, $\epsilon$ випадковою величиною, підкореною нормальному закону розподілу, дозволить скористатися відомим апаратом теорії імовірності та перевірки багато альтернативних статистичних гіпотез та робити розрахунки за даними існуючої статистичної вибірки. Статистична обробка даних, отриманих при виконанні силами оборони держави завдань за призначенням дає змогу отримати вихідні дані та обрахувати прогнозовані оптимальні ймовірності розподілу витрат матеріально-технічних засобів відповідно до поточного, середнього, капітального ремонту та безповоротних втрат.

Ключові слова: логістичне забезпечення; незнижувальний запас матеріально-технічних засобів; модель Уілсона; економіко-математичні моделі; багатоальтернативні статистичні гіпотези; континуальне лінійне програмування.

\section{Применение вероятностных экономико-математических моделей для оптимизации планирования неснижаемого запаса и повышения эффективности логистического обеспечения сил обороны государства без снижения уровня надежности}

\section{Е. А. Сидоренко, Е. А. Макогон, Н. В. Корда, Ю. В. Бабкин, А. В. Исаков, И. В. Калинин}

Аннотация. Предметом изучения в статье является логистическое обеспечение сил обороны государства. Целью исследования является разработка вероятностной экономико-математической модели управления запасами для планирования неснижаемого запаса средств материально-технического обеспечения сил обороны государства. Задачи исследования: сформулировать задачу определения размера неснижаемого (резервного) запаса материальнотехнических средств при условии, что максимально возможное значение вероятности его исчерпания течение определенного периода не превысит предельного значения в терминах экономико-математической модели Уилсона; путем статистической обработки данных наблюдений действий сил обороны государства при выполнении ими задач по назначению представить задачу определения оптимального неснижаемого запаса по видам затрат средств материально-технического обеспечения без снижения уровня надежности как задачу проверки многоальтернативного статистических гипотез; на основании решения задачи континуального линейного программирования определить оптимальный неснижаемого запаса соответственно характеру расходов с целью повышения эффективности управления логистическим обеспечением сил обороны государства средствами материально-технического обеспечения. Методологической основой исследования стали общенаучные и специальные методы научного познания. Получены следующие результаты. Расходы запасов материально-технических средств при выполнении силами обороны государства задач по назначению в течение определенного периода времени нормально распределенной случайной величиной с математическим ожиданием и среднеквадратического отклонением, рассчитанными по результатам статистической обработки данных. Задача определения оптимального неснижаемого запаса по видам затрат материально-технических средств без снижения уровня надежности сформулирована как задача проверки многоальтернативного статистических гипотез и решена как задача континуального линейного программирования. Выводы. Определение размера неснижаемого (резервного) запаса материально-технических средств подразделений сил обороны государства при выполнении ими задач по назначению при условии, что максимально возможное значение вероятности его исчерпания течение определенного периода не превысит предельного значения целесообразно сформулировать в терминах экономико-математической модели Уилсона. Предположение о том, что расходы запасов материально-технических средств при выполнении силами обороны государства при выполнении задач по назначению, является случайной величиной, подчиненной нормальному закону распределения, позволит воспользоваться известным аппаратом теории вероятности и проверки много альтернативных статистических гипотез и производить расчеты по данным существующей статистической выборки. Статистическая обработка данных, полученных при выполнении силами обороны государства задач по назначению позволяет получить исходные данные и рассчитать прогнозируемые оптимальные вероятности распределения расходов материально-технических средств в соответствии с текущим, среднего, капитального ремонта и безвозвратных потерь.

Ключевые слов а : логистическое обеспечение; неснижаемый запас материально-технических средств; модель Уилсона; экономико-математические модели; многоальтернативного статистические гипотезы; континуальное линейное программирование. 